\title{
Collaborative and Linkage Programs Between TVET Institutions and the Industry. A Case of TVET Institutions in North Rift Region, Kenya.
}

\author{
*Wilberforce Manoah Jahonga ${ }^{1}$, Bernadette Canute ${ }^{1}$, Elizabeth J. Murey ${ }^{2}$, \\ Catherine Otunga $^{1}$, Dr. Catherine Kiprop ${ }^{2,}$, Dr. Kosgey Z. \\ ${ }^{1}$ Sigalagala National Polytechnic, P.O Box, 2966, Kakamega-Kenya \\ ${ }^{2}$ Moi University, P.O.Box 3900, Eldoret-Kenya
}

\begin{abstract}
The industry-institute relationship as a result of industrial attachment program among TVET institutions plays a key role in ensuring up to date skill transfer among TVET graduates. This paper highlights the various forms of collaboration between TVET institutions and Industry in Kenya through an industrial attachment program. The study focused on TVET institutions in North Rift region, Kenya. The study adopted descriptive survey design. Stratified proportionate simple random sampling technique was used to select a sample of 245 respondents which included 30 lecturers, 3 industrial liaison officers, 5 workplace supervisors and 207 TVET students. The research instruments for data collection were; the structured questionnaire and interview schedule. Data was analyzed using descriptive statistics. Descriptive statistics included frequencies, percentages and mean. Data was presented in form of pie charts, bar charts, and tables. The study recommends that training institutions need to strengthen institute-industry linkage to ensure quality training.
\end{abstract}

Keywords: Industrial Attachment Program, collaboration, industry,

\section{Introduction}

The interaction between research institutions and the industry has been considered a strategic instrument for national and regional innovation, competitiveness, and economic growth(Rast et al, 2012). TVET institutions operate in an environment characterised by fast technological progress, emerging careers, changing jobs requirements and increased competition. These changes have necessitated an industry-institute collaboration in order to address this challenge (Plewa \& Quester, 2008). Additionally,Hernes and Martin (2001) observe that University-institute partnership is a relatively new phenomenon that emerged during the past century and has strongly expanded in scope and number over the recent decades It covers a wide range of diverse realities from the more traditional, such as placement schemes, staff exchanges, consultancy services, continuing professional development, joint research and development, to the recent areas such as small enterprises development-the creation of spin offs for the joint commercialization of Research and design for collaborative research at the national and international level. Companies that collaborate with learning institutions typically have higher productivity rates than companies that do not have such collaboration (Cedefop, 2016; Malairaja \& Zawdie, 2008). Such collaboration has the benefits of producing quality products at a competitive cost due to research and development. Kenya vision 2030 places a strong emphasis on linkage between training institutions and the industry. The Sessional Paper No 1 of 2005 recommended that training institutions must strengthen the level of collaboration with industry for meaningful education to take place. The paper asserts that industrial harmony is critical in order to enhance productivity and firm competitiveness. The Third international congress on technical and vocational education and training on "transforming TVET: Building skills for work and life" in Shanghai, China recommended that TVET delivery must involve a broader partnership with multiple stakeholders. This in turn calls for greater coordination. Participants acknowledged the crucial role of national, regional and international coordination and cooperation between partners, as well as linkages with social partners and industries, in order for TVET to become accessible and efficient in various and alternative ways linked to lifelong learning. Effective stakeholder dialogue for curriculum development, program design, delivery and governance is needed. The conference concluded that the new paradigm of TVET should be conceived of in such a way that training systems can respond to the demands of the labour market, while at the same time helping citizens achieve skills required for work and for lifelong learning. Evidence suggests that individuals who complete apprenticeships and traineeships are more likely to be employed, more likely to earn a higher salary and more likely to have full time rather than part time employment, than those who don't complete.(VAGO, 2014). An industrial Programme if well-coordinated should bring strong ties between training institutions and the industry (Klitkou et al. 2007; Majumdar, 2010). Much has been said about this relationship. Kenya vision 2030 notes that 'poor linkage between the labour market and training institutions has led to skill mismatch and underdevelopment.' This linkage is partly possible if both parties realize that the 
relationship that is to exist should be symbiotic in nature. Industries have to accept that any workforce comes from training institutions and therefore should not take advantage of the cheap labour provided by the attachés at almost free cost. Training institutions on the other hand have to note that their success depends on their absorption level of their graduates into the job market.

In contrast, training systems are under pressure because technological change, the shortening of the product cycle and new forms of workplace organizations are changing the context in which decisions about training are made. The training has to ensure that the labour force meets the ever more stringent national and international qualification requirements (ILO, 2006). It's in this context that ILO regarded basic education as a necessary but not sufficient condition for adapting training to the challenges of economic globalization. The organization recommended promotion of partnerships with business as one of the solution to these challenges.

The rate of technological advancement seems to be faster compared to the classroom experience students are often exposed to.Teuber \& Backes(2012) opine that innovation appears to be hampered in companies in which academically qualified workers only have unskilled workers to collaborate with, because they lack the knowledge and professional language link that vocational workers provide Burns(2002) argues that while it is unlikely that a surgeon from a hundred years ago could work, walk into an operating theatre in today's world and set the work, there is no doubt that a teacher from a hundred years ago could walk into a modern classroom, pick up the chalk and carry on. Teacher being the conduit through which the stuff of learning is piped into learners, need to abreast themselves with modern technology. This can be enhanced through collaborative programmes between training institutions and the industry. This relationship facilitates quality experience for the students as well as contributing to the development of the workplace (Groenewald, 2004). He further argues that this collaboration should not be seen as a panacea, however but a critical reflection on these and other research capacity. Partnerships reveal significant problems in translating intentions into successful practice.ILO (1997) argues that collaboration may occur at many levels including the macro (policy) level, the meso (sectoral) level and the micro (enterprise) level. The scope ranges between the national training policies, legislation and systems by government and employers to local training. The various strategies to strengthen this collaboration include; involving all stake holders concerned with technical education both in formal and informal sector, promoting contacts and cooperation between managers of the education system and the working world, involving industry in needs analysis, curriculum development and certification, involving the community and local stakeholders in local development projects, inducing training institutions to participate actively in these projects by allowing use of their facilities, producing goods and providing services, bringing training sites closer to production sites. Bertrand (2004) adds that other forms of partnership include; representation of the social partners on training boards and committees, service support such as knowledge transfer through workshops and conferences, financing institutional programmes by industries such as excursions, technical assistance, philanthropic donations, provision of bursary to needy and bright students and through collaborative research and development.

The search for a better match between jobs and training is based on a two horned problem; firstly the skilled labour as reported by many employers and secondly the pace of technological change requires workers to have new qualification in order to perform the tasks required in modern jobs and thus raise competitiveness(Poupard et al, 1995). Further, companies have changed the way they do business and how workers have more responsibility and contribute more to businesses in order to meet the demands of today's competitive economy (Sweet, 1995). These can be bridged through such collaborative programmes and quicken the absorption rate and transitions of students from class to work. Ahmad and Junaid (2010) sum it all by stating that unless and until the space between academia and industry is bridged attaining of high standards in the working of both the university and industry and realization of the goals of national economic development would be next to impossible. It's true that training institutions are not mere adjuncts to industry or students a human means to material means on the contrary, they should provide learners with critical spirit and intellectual capacity to transform an industrial and educational structure. A balance between the expectations of both parties has to be struck to avoid mistrust and exploitation. The argument by Scheffler (1995) should be believed; that 'in an attempt to increase collaboration with the industry, trainers should be called upon to think of knowledge as fruit of original inquiry. Industry/firms or employers should not be seen as the only ones in possession of established facts which are often stubborn, inert and unquestionable. There should be free flow of information and ideas between training institutions and the industry to enhance development.

\section{Methodology}

The study adopted descriptive survey design. Stratified proportionate sampling was used to select respondents from training institutions. Stratified proportionate simple random sampling technique was used to select a sample of 245 respondents which included 30 lecturers, 5 workplace supervisors and 207 students and 3 ILOs selected from a target population of 986 . The research instruments for data collection were; the structured 
questionnaire and interview schedule. Data was analyzed using descriptive statistics which included frequencies, percentages and mean.

\section{Forms of collaboration}

\section{Findings and Discussion}

Forms of collaboration were grouped into five areas. This were; provision of placement opportunity by industry, provision of training and learning materials to institutions by industry, training institutions provide further training to staff from industry, Industry providing insurance cover for students on IAP and existence of collaborative research between training institutions and the industry. The figure below shows the mean ratings of lecturers who responded to this question.

Figure 1: Forms of collaboration

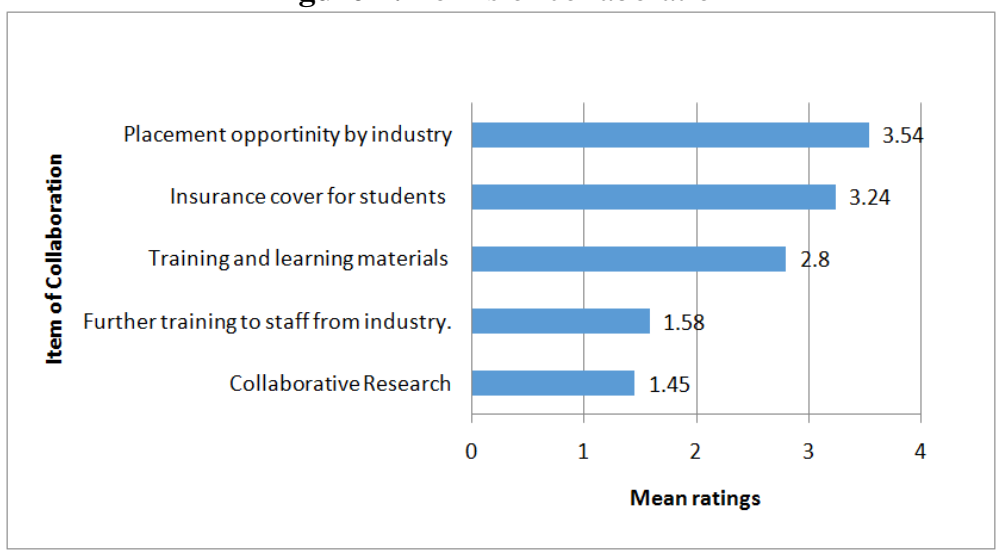

From figure 1 above, it was observed that respondents ranked placement opportunity by industry with the highest mean of 3.54. This was followed closely by provision of insurance cover to students by industry at a mean of 3.24, training and learning materials at 2.8, further training of staff by the industry at 1.58 and collaborative research was ranked as the least with a mean rating of 1.45. It appears that training institutions generally have a more visible form of collaboration through industrial attachment. It's however expected that there should be deeper partnerships between training institutions and industry in terms of collaborative research. This confirms the recommendation of sessional paper No. 1 of 2005 that training institutions must strengthen the level of collaboration with industry for meaningful education to take place. Hernes and Martin (2001) observe that University-institute partnership though new phenomenon covers a wide range of diverse realities from the more traditional, such as placement schemes, staff exchanges, consultancy services, continuing professional development, joint research and development, to the recent areas such as small enterprises development-the creation of spin offs for the joint commercialization of Research and Design for collaborative research at the national and international level. TVET institutions are yet to realize the strong partnership with industry in a more dynamic way. Perhaps this explains why often times student will spend a lot of time looking for placement places in the industry/firms. This is reinforced by the fact that managers who are expected to be the key link persons between the industry and the institute rarely visit industry. The visits by TVET managers was seen as another pillar that strengthens institute-industry relation and enhances student placement as shown in figure 2 below.

Figure 2: Visit by TVET Managers in the Industry

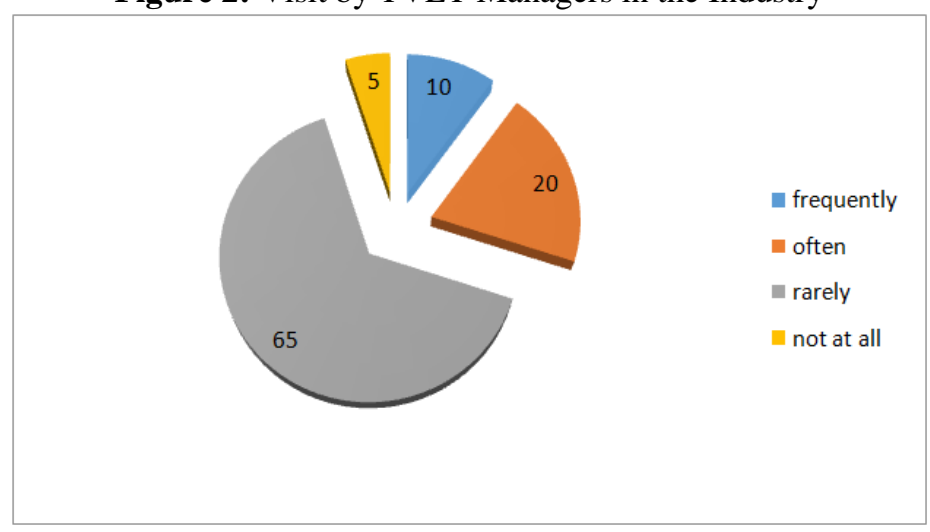


From figure 2 above, the study sought to find out whether the visits by lecturers and managers in TVET institutions were sufficient enough to elicit strong partnership. The findings indicated that $10 \%$ said frequently, $15 \%$ said often, $70 \%$ said rarely and 5\% said not at all. This indicates that over $70 \%$ of respondents rarely makes industrial visits as an important aspect of industry institute collaboration. Communication has been described as the glue that holds together partners in organizational relationships (Mohr \&Nevin 1990; Morgan \& Hunt (1994).It is therefore recommended that managers of training institutions should strengthen communication and industrial visits if ever attachment has to be effective. Teachers need to be facilitated by a managerial and administrative system that is designed to foster improved learning outcomes. In a study to establish the link between communication and trust in an industry-institute relationship, Mora et al. (2004) found that there is a positive relationship. The argument that industrial visits are seen as unnecessary does not indicate that they are not important (Donkor et al, 2005).

\section{Enhancing industry-institute interaction}

On the question as to how the industry-institute interaction can be enhanced, the following suggestions were made by respondents; Training institution should give token reward to firms that host student on attachment. This was seen as a way of encouraging industry to continue absorbing most of students for attachment. Secondly, industrial visits by TVET managers should be enhanced as a way of increasing industryinstitute partnership and give managers firsthand experience on the happenings in the industry. Thirdly, joint research between training institutions and the industry on specific projects or assignments should be enhanced. This form of interaction increases the bond between institutions and the industry which is healthy for academic and economic achievement. Fourthly, industry has a social corporate responsibility to support institute activity such as games and sports among others. Lastly industry should continue providing opportunities and avenues for employment to TVET graduates.

These findings show that relations of TVET institutions with the socioeconomic environment depend however widely on the particular dynamism of certain individuals, often teaching personnel with working experience and personal contact with the formation of policy priorities, but also top level management support which is necessary to back up academic department (Martin, 2000).Even if there is no collaborative programmes and activities conducted by industry and institutions, its often necessary as part of the sensitization strategy to inform potential enterprises that the tertiary education establishment has interesting things to offer (Martin, 2000). Further management should acknowledge certain density of informal relations with industry and advance a policy objective to institutionalize and foster such relations. There should be flexibility necessary to tackle this dynamism (Hernes and Martin, 2001) The study further sought to establish from respondents who were lecturers to what extent they believed the interaction with industry was strong. The table below shows the responses from respondents on the various items relating to institute -industry relationship.

Table 1: Summary of industry-institute Interaction with Industry

\begin{tabular}{|c|c|c|c|c|}
\hline & GE & SE & $\mathrm{L}$ & VN \\
\hline Item of interaction & \multicolumn{4}{|c|}{ Percentages } \\
\hline Training institutions have good cooperation with workplace supervisors. & 59.9 & 24.7 & 9.9 & 5 \\
\hline $\begin{array}{l}\text { There is sufficient interaction between workplace supervisors and lecturers to } \\
\text { ensure quality student training. }\end{array}$ & 19.8 & 40.1 & 19.8 & 14.8 \\
\hline $\begin{array}{l}\text { There is no mechanism to promote interaction of training institutions with the } \\
\text { industry. }\end{array}$ & 69.7 & 19.7 & 9.8 & 0 \\
\hline Lecturers do not make individual initiative to promote industry-institute linkage. & 74.6 & 20 & 5 & 0 \\
\hline There is regular exposure of lecturers to industry. & 5 & 24.7 & 54.9 & 14.8 \\
\hline Training institutions provide opportunity for lecturers to meet staff from industry. & 0 & 10 & 70 & 20 \\
\hline The institute management supports industry-institute linkage. & 5 & 14.8 & 59.9 & 19.8 \\
\hline
\end{tabular}

From table 1 on the question whether training institutions secure good cooperation with workplace supervisors in the industry, $97(59.9 \%)$ said to great extent, $40(24.7 \%)$ said to some extent $16(9.9 \%)$ said little while $9(5 \%)$ said virtually nothing. On the question whether there is sufficient interaction between workplace supervisors and lecturers to ensure quality student training, 32(19.8\%) said to a great extent, 65(40.1\%) said to some extent, 32(19.8\%) said little and 24(14.8\%) said virtually nothing. on the question whether there no mechanism to promote interaction between industry and training institutions, $119(69.70 \%)$ said to a great extent, $32(19.7 \%)$ said to some extent, $16(9.8 \%)$ said little. On the question whether lecturers make individual initiative to promote industry-institute linkages, $121(74.6 \%)$ said to a great extent, $20 \%$ said to some extent, and $5 \%$ said little. There was zero response for virtually nothing. On the question whether there was regular exposure of lecturers to industry, $9(5 \%)$ said to a great extent, $40(24.7 \%)$ said to some extent, $89(54.9 \%)$ said while $24(14.8 \%)$ said virtually nothing. on the question whether institute management supports industry-institute linkage, $9(5 \%)$ said to a great extent, $24(14.8 \%)$ said to some extent, $97(59.9 \%)$ said little and $32(19.8 \%)$ said virtually. 
In an interview, the researcher asked workplace supervisors how IAP was important in creating a linkage between students and TIVET and industry. One workplace supervisor said that IAP clearly creates a link between the college and the industry; in fact it is the main partnership between the industry and the college. In this partnership, the industry benefits from the labour that the students offer while the students benefit from the experience that the industry offers.

These finding contradicts that of Martin (2001) who argues that TVET institutions and industry pursue different objectives and face different time constraints. There are different time horizons for research outputs; short and definite in case of industry; long and indefinite and flexible in the case of academic staff. Industry strives to benefit from practical exploitation of results and optimum testing whereas university staff seeks for knowledge, new theories and thoroughness. More so the private sector generally prefers confidentiality in terms of research results, whereas university seeks to publish. Even if collaboration between training institutions with industry is enhanced, there is indeed a dichotomy between the academic and the industry sphere to the detriment of the students' learning. Additionally, Altbach (2009) confirms that tertiary institutions worldwide cannot develop research capacity in all fields and disciplines. Few manage to marshal the human and financial resources to lead engagement in research.

\section{References}

[1]. Altbach S.(2003) Academic dependency and the global division of labour, In the social science in current sociology 51(6),599-613

[2]. Bertrand, O. (2004). Planning Human Resources. Methods, experiences and practices,(2nd ed.).Paris: IIEP-UNESCO.

[3]. BillettS.(2002).Learning through practice: beyond informal and towards a framework for learning through practice in Revisiting Technical and Vocational Education in sub-Saharan Africa: An Update on Trends, Innovations and Challenges UNESCO, IIEP.

[4]. Burns, R.B. (2000). Introduction to research methods in education. Melbourne; Longman Cheshire pty limited.

[5]. Cedefop (2016). Governance and financing of apprenticeships. Luxembourg: Publications Office. Cedefop research paper; No 53.

[6]. Gamble J.(2002). Why improved formal teaching and learning are important in technical and vocational education and training (TVET)orientation in Revisiting Technical and Vocational Education in sub-Saharan Africa: An Update on Trends, Innovations and Challenges (pp.206-238). Paris: UNESCO.

[7]. Groenewald, T.(2004). Towards a definition of cooperative education in MC Dermott, K. (2008).

[8]. Addressing the weak link. Enhancing support for the sponsors of students' placements in cooperative education. Asian Pacific Journal of Cooperative Education, , 9(1), 91-111

[9]. Grubb, N.(2002). An occupation in harmony (working paper, OECD career guidance policy review. Paris: OECD.

[10]. Gundmund, H., \& Martin M.(2001). Management of University-Industry Linkages. Results from policy forum held at IIEP, Paris 12 June 2000. IIEP Paris

[11]. Hanushek, E.A. and Wobmann, L. (2007). The Role of Education for Economic Growth.

[12]. World Bank Policy Research. Working Paper No 4122. Washington, DC: World Bank.

[13]. H. Fayol, (1983). General and Industrial Management. G.A Cole: Essex,

[14]. ILO. 2006. Career Guidance: a Resource Handbook for Low- and Middle-Income Countries. Geneva, International Labour Office (ILO).

[15]. ILO. (2012). Joint ILO-UNESCO Committee of Experts on the Application of the Recommendations concerning Teaching Personnel (Geneva, 8-12 October 2012) Geneva: ILO

[16]. Kothari C.R. (2004).Research Methodology. (2nd ed.). New Delhi: New Age International Publishers,

[17]. Majumdar (2010). Industry-Institute Interaction to Public-Private Partnership: A Journey to Excellence. Retrieved September 19, 2011 from

[18]. www.cpsctech.org/management/dg/sl/6-industry-institute\%20interaction $\% 20$ to $\% 20$ ppp.pdf

[19]. Malairaja, C., Zawdie, GScience parks and university-industry collaboration in Malaysia.Technology Analysis and Strategic Management,.2008, 20: 727-739.

[20]. Martin, M. (2000). Managing university-Industry Relations. A study of institutional practices from 12 different countries. IIEP,Paris

[21]. Morgan, R. M., \& Hunt, S. D. (1994). The commitment-trust theory of relationship marketing.Journal ofMarketing, 58(3), 20-38.

[22]. Plewa, C., \& Quester, P. (2008). A dyadic study of 'champions' in university-industry

[23]. relationships. Asia Pacific Journal of Marketing and Logistics, 20(2), 211-226.

[24]. Rast, S., Khabiri, N., Senin, A.A. Evaluation framework for assessing university-industry

[25]. collaborative research and technological initiative. Procedia-Social and Behavioral Sciences, 2012, 40: 410-416.

[26]. Sweet, R. (1995). Linking schools and workplaces: lessons from Australia and abroad, Occasional Paper no. 1. Sydney, NSW, Australian Student Traineeship Foundation.

[27]. VAGO(2014); Apprenticeship and traineeship completion, Melbourne 